\title{
Landslide impacts and management in Nanka area, Southeast Nigeria
}

\author{
Ogbonnaya Igwe ${ }^{1}$ and Chuku Okoro Una ${ }^{2^{*}}$ (B)
}

\begin{abstract}
The devastating impacts and mitigation measures for landslides in Nanka, Southeast Nigeria were studied. A procedure encompassing field mapping, laboratory analysis and limit equilibrium simulations were employed in the study. A total of 120 landslides in this area were documented during the field study. They were mainly shallow landslides with depth range of $0.2 \mathrm{~m}-1.8 \mathrm{~m}$ and slope angle range of $36^{\circ}-65^{\circ}$. This study revealed that landslides in this area occur mainly during the rainy season, and are triggered by water infiltration in slopes with high gradient, where poorly consolidated sands overlies less permeable silty clay units in the Nanka Formation. The increase in pore water pressure due to soil saturation leads to reduction of the shear strength and loss of apparent cohesion. Geotechnical laboratory analysis showed that the thin silty clay soils found in the area have very high plasticity, while the sands are non-plastic. The limit equilibrium simulations revealed that as the slope angle increases, the potential slip mass volume increases. Our study in Nanka revealed that landslides have negatively affected the topography/morphology, settlement areas, agricultural lands and vegetation/land cover of the area and many areas are also threatened by this phenomenon. Standard mechanical drainage system and biotechnical slope protection have been suggested as mitigation measures. Finally, we suggested that landslide hazard information should be incorporated into long-term plans for Nanka and other areas prone to landslides, the public should be aware of the hazards and preventive measures.
\end{abstract}

Keywords: Impacts, Limit equilibrium, Mitigation, Biotechnical

\section{Introduction}

Landslide occurs in different parts of the world, under all climatic conditions and environments. It is a major natural hazard in which its global concern keeps increasing yearly. In many regions of the world, the impacts of landslides have been cataclysmic with damages worth several millions of dollars in monetary losses, and are responsible for thousands of deaths and injuries annually. Regularly, they cause long-term economic disruption, population displacement, and negative effects on the natural environment, (Ancuța et al. 2007; Highland and Bobrowsky 2008; Igwe, 2015). Though landslides can occur in different parts of the world, their mechanisms, impacts and management is often determined by the geology, hydrogeology and geomorphology of the area. It means that the risk associated with landslides is area dependent, which implies that mitigation techniques

\footnotetext{
* Correspondence: unachuku@gmail.com

${ }^{2}$ Department of Applied Geology, Wesley University, Ondo, Nigeria

Full list of author information is available at the end of the article
}

should be area dependent, though some management measures can be universally applied. Globally, many researchers such as Dai et al. (2002), Schuster and Highland (2003), Lateltin et al. (2005), Chen (2008), Chowdhury and Flentje (2014) and Kazmi et al. (2017) have reported the devastating impacts of landslides and possible mitigation measures such as slope modification, bioengineering, slope reinforcement, construction of retaining walls, check dams etc. Authors like Ogbukagu (1976) and Okagbue $(1986,1992)$ have reported the mechanisms of landslides in Nanka area and some of the devastating socio-economic impacts. In this research, we will present our latest findings on the impacts of landslides to the over-all environment, comprising the people, their livestock and farms, structures, and the morphology of the earth's surface in Nanka area, Orumba North Local Government Area, Anambra State, Southeast Nigeria (Fig. 1). Our report will also suggest mitigation measures to manage this phenomenon. 


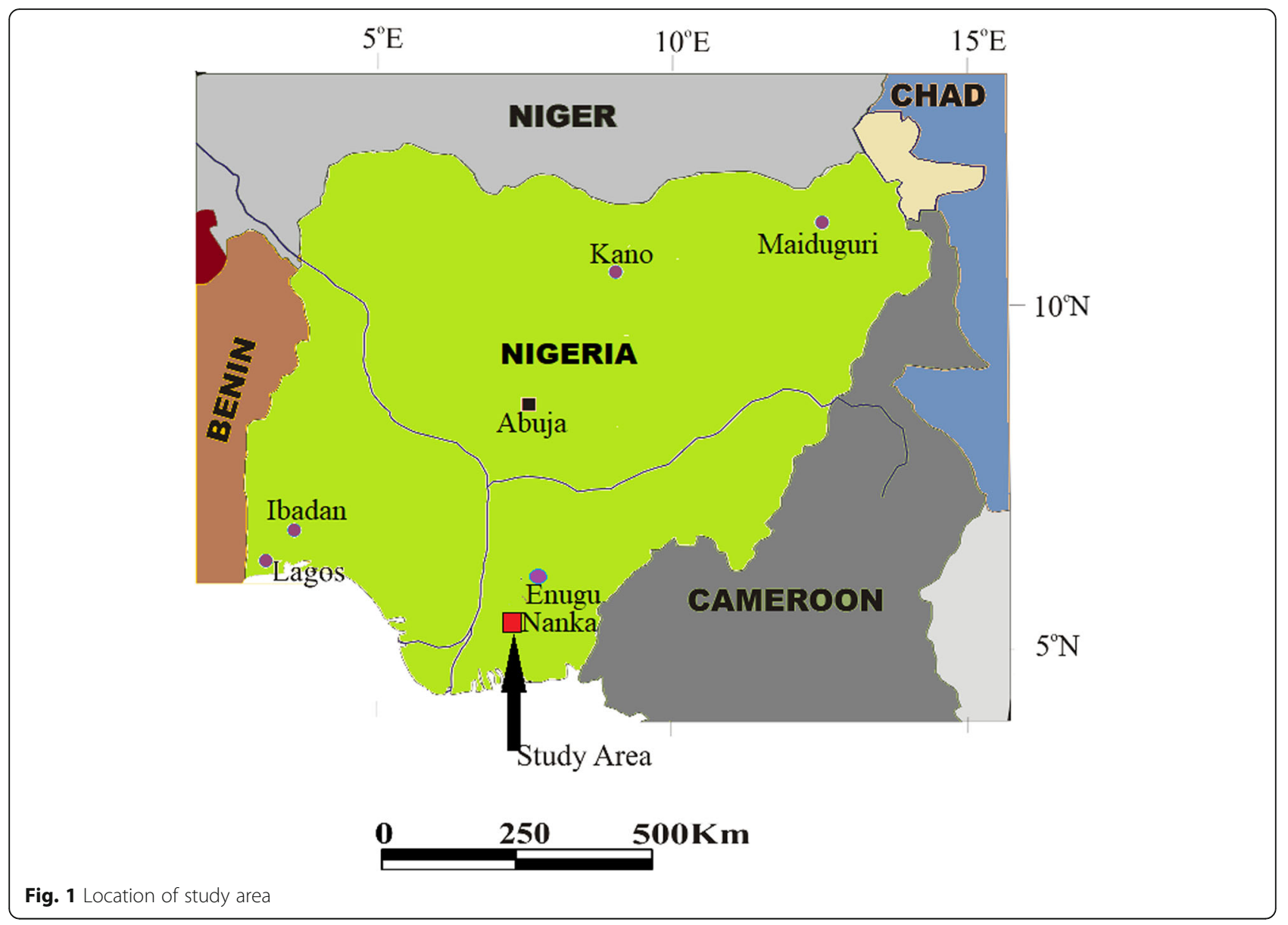

\section{Geology and geomorphology of the study area}

The study area is part of the Campanian to Eocene Anambra basin, which was formed as a result of compressive movement along the Northeast - Southwest axis of the Aptian - Santonian Abakaliki basin. This tectonic activity resulted in the folding and uplift of the Abakaliki basin into an anticlinorium and formed the Anambra basin on the Southwest and Afikpo syncline on the Southeast. This enforced the depocenter to move to the recently formed Anambra Basin and the Afipko syncline (Murat 1972; Benkhelil 1989; Kogbe 1989; Oboh-Ikuenobe et al., 2005 and Nwachukwu et al. 2011). The Nanka Formation (Early Eocene) which is underlain by Imo Shale (Paleocene) is the main exposed Formation in the study area (Nwajide 1980).

Nanka Formation consist of unconsolidated or poorly consolidated sands with thin claystone and siltstone bands. The sand is poorly-sorted, cross-bedded and medium to coarse grained with variegated colour; yellow to brown, pink to purple to iron stained on weathered surface and white to milky white on fresh surfaces (Fig. 2). The Clay/Shale beds are dark grey to grey with specks of mica, pyrite and gypsum in some places. Sandstone consists of quartz arenites with predominantly monocrystalline quartz (Nwajide 1977; Egboka and Okpoko 1984; Ezechi 1987 and Okagbue 1992).

Nanka is part of a regional system of escarpments; it lies near the minor escarpment of the Awka-Orlu uplands formed by the Nanka Formation (Okagbue, 1992). Nanka has an undulating topography ranging from gently sloping lowlands to slightly steep highlands (Figs. 3 and 4). Based on documented landslides, Nanka elevation ranges from 170 to $373 \mathrm{~m}$ above sea level, with average elevation of $222 \mathrm{~m}$.

\section{Climate}

South-East Nigeria is generally a tropical climate with two distinct (rainy and dry) seasons. The rainy season begins in April and ends in October, while the dry season begins in November and ends in March. Records of rainfall showed high values within the months of May to early August when there is a rainfall break and resumes in late August to end of October with higher values. There is virtually little or no rainfall from November to March. The average monthly temperatures vary from 22 ${ }^{\circ} \mathrm{C}$ to $28{ }^{\circ} \mathrm{C}$ in the rainy season and between $28^{\circ} \mathrm{C}$ and $32^{\circ} \mathrm{C}$ in the dry season. Intense and short duration rainfalls characterize the outset of rainy season. Annual 


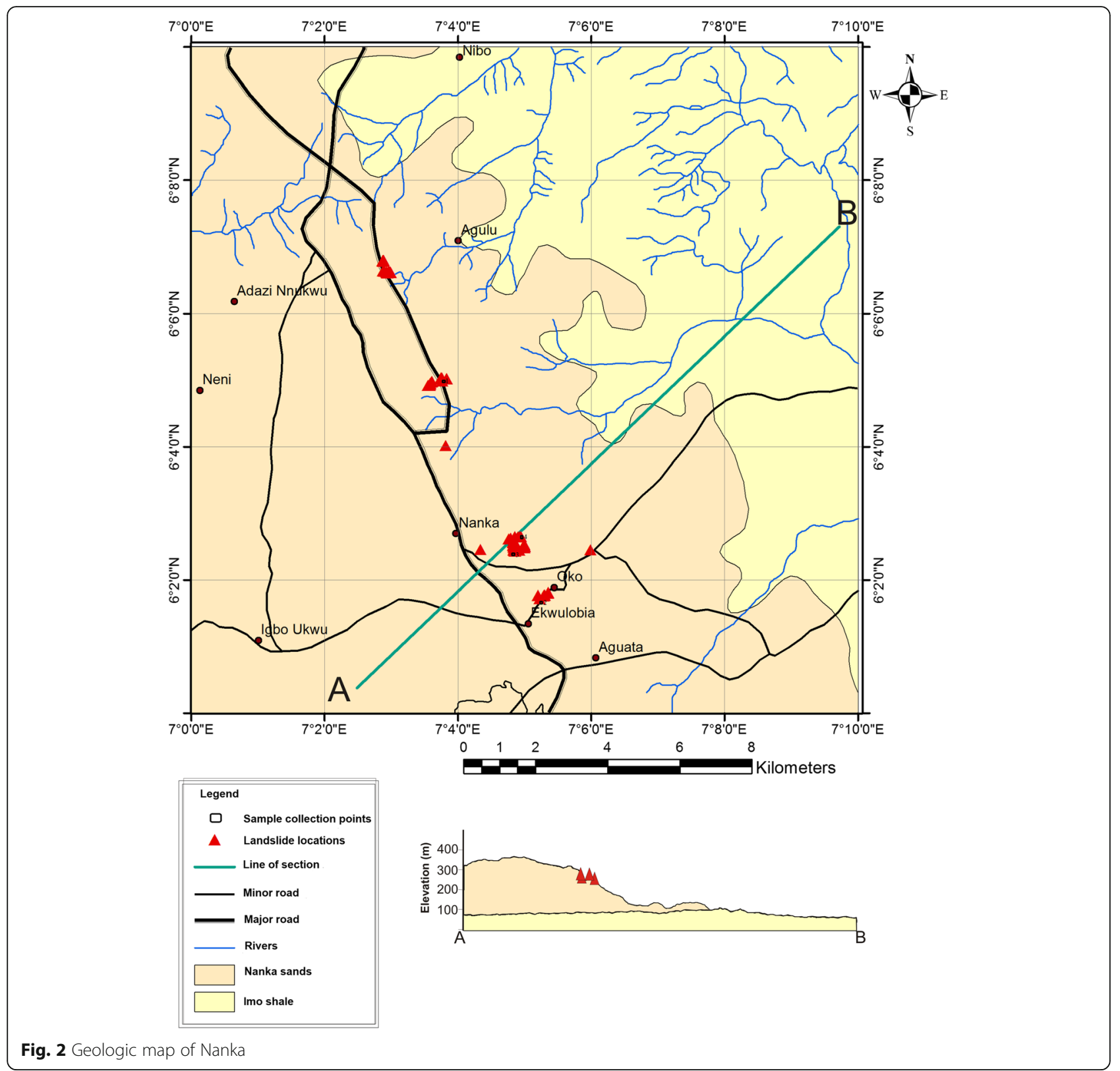

rainfall ranges between $1500 \mathrm{~mm}$ to $2500 \mathrm{~mm}$ (Monanu and Inyang 1975; Ezemonye and Emeribe 2012 and Igwe et al. 2013). South-East Nigeria lies in the Lowland rainforest natural vegetation belt with evergreen trees in the south, and gradually gives way northward to rainfallsavannah forest characterized by trees interspersed with grass. The natural vegetation of the study area has been disturbed over the years through forest clearance and bush burning for agriculture (Ibeanu and Umeji 2003). The precipitation regime is fairly regular. The rainfall amount in the month of May appear to support the idea that intense/ short duration rainfall is a main factor in landslides trigger (Igwe et al. 2013). Rapid landslides are usually initiated within hours of intense rainfall (Terlien 1998).

\section{Nature of landslides in Nanka}

One hundred and twenty (120) landslides were documented within Nanka and its neighbouring towns of Oko and Agulu. We have grouped them under Nanka because they are all underlain by the Nanka Formation and have similar mechanism of occurrence. Complex gully erosions have devastated Nanka area; the most spectacular is the Nanka-Oko gully erosion, which has destroyed several homes and farmlands (Fig. 5). Most of the landslides in Nanka occur along the gully channels. The slope angles created by these gullies vary from $36^{\circ}$ $65^{\circ}$, with average slope angle of $48^{\circ}$. The characteristics of the soils, the nature of the slopes, and rainfall combine to produce slides that vary in scale and structure. 


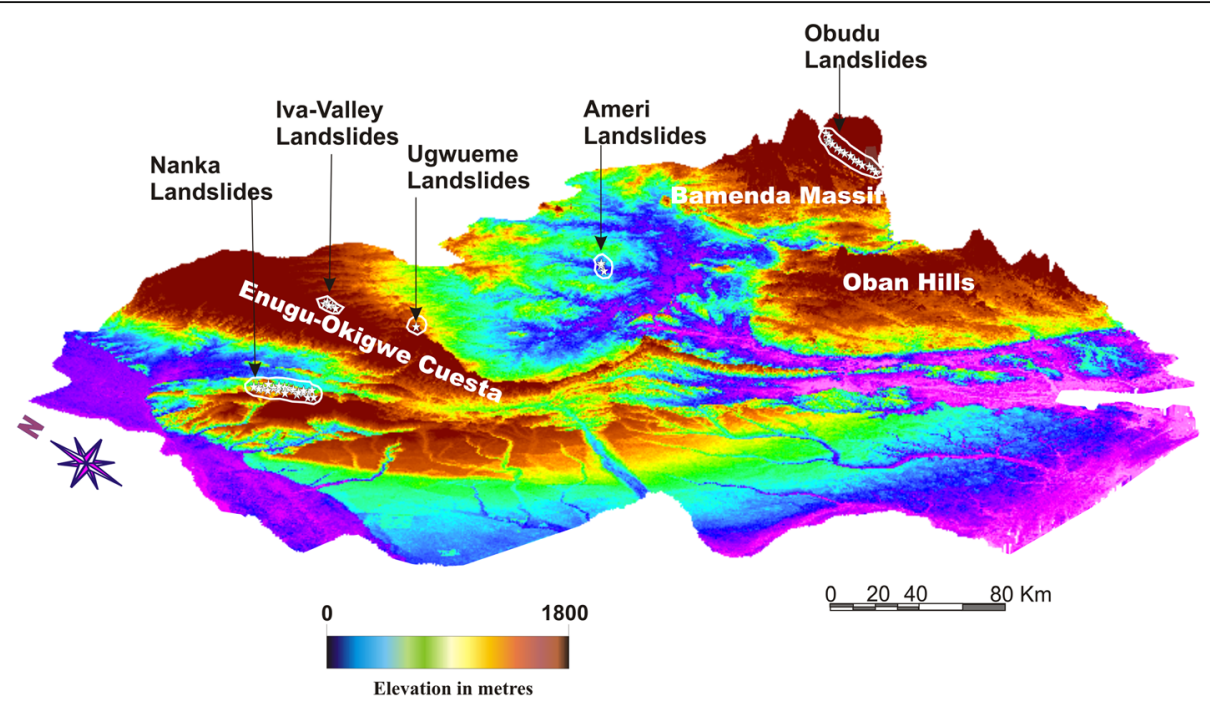

Fig. 3 The 3D ASTER DEM revealing the geomorphologic features and landslide Areas inSoutheast Nigeria

Most of the landslides in Nanka are shallow translational debris slides, slumps and occasional debris topples (Fig. 5). Landslide depths in this area ranges from $0.2-1.8 \mathrm{~m}$, with average depth of $0.74 \mathrm{~m}$. Okagbue (1992) stated that topples (rotational falling) occasionally occur in the area. The impermeable clay beds separating the lower sand horizon acts as gliding plane for several large slumps (Ogbukagu 1976; Okagbue 1986). Many of the slumps are known to occur within the near homogeneous soil overburden (Okagbue, 1992).

Slopes in Nanka frequently fail during short or long, intense rainfalls mostly at the beginning of rainy season. The effects of high pore water pressures created by rainfalls during the rainy season and the swelling behaviour of active clay minerals in interbedded clay/ shale units have been reported as the mechanism of landslides in Nanka (Egboka and Okpoko 1984; Okagbue 1992). Brand et al. (1984) noted that majority of landslides in Hong Kong were induced by concentrated, short-duration rainfalls of high intensity. Matric suction at shallow depths partially or completely disappears when rainfall infiltrates the soil and therefore, the slope may fail. The reduction in soil matric suction decreases the soil shear strength, and consequently causes the slope to become unstable and fail (Li et al. 2005).

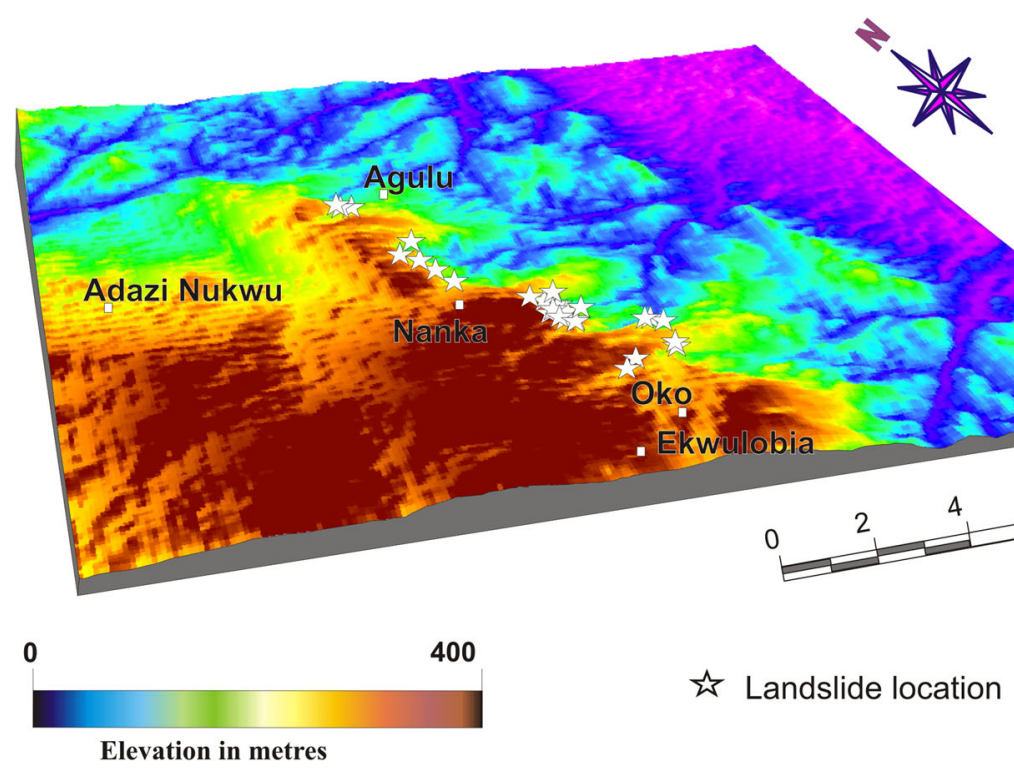

Fig. 4 The 3D ASTER DEM revealing the geomorphologic features and landslide dominatedAreas in Nanka 


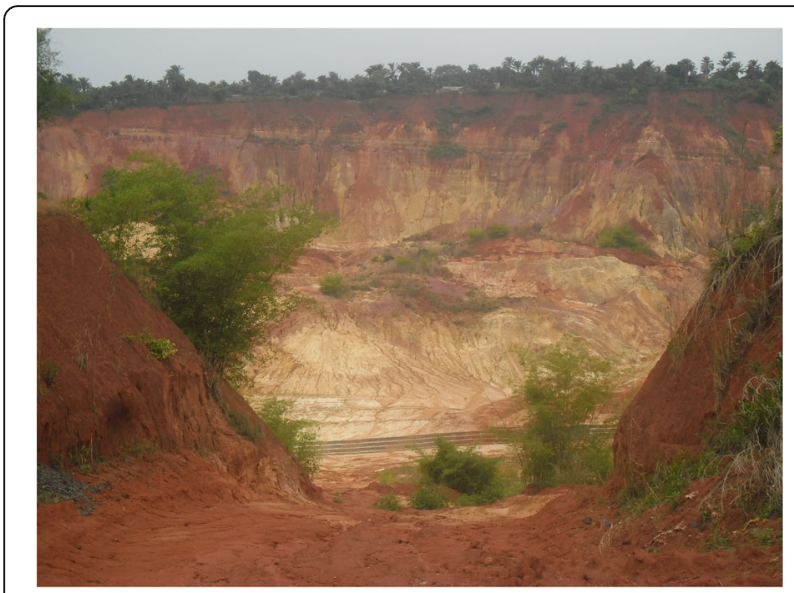

Fig. 5 Nanka complex gully erosion

The triggered slides in Nanka are mainly shallow with short run-out distance $(<200 \mathrm{~m})$. The average landslide run-out distance in this area is $13.8 \mathrm{~m}$.

\section{Methods}

Field surveys covering Nanka and neighbouring areas were undertaken to study landslides and their impacts to the over-all environment. Landslides were described in the field to allow classification according to Cruden and Varnes (1996), Hungr et al. (2001). The extent of the landslide bodies were mapped from crown to toe of rupture. Details of the nature and types of materials associated with slope movement, slope angles, depths, width and lengths of landslide, elevation of landslide source and toe were also recorded. Measurements essential to the preparation of an adequate geologic map were taken at various locations within the study area. Geological cross-sections were then made to study the morphology of the slides. Global positioning system (GPS) was used to get the exact locations of landslides in the field. These measurements were integrated with ASTER data to prepare adequate 3D digital elevation map (DEM) of the study area revealing landslide locations. Samples were collected at different landslide locations and subjected to laboratory analysis to obtain geotechnical data and parameters needed for limit equilibrium simulations.

Samples were analyzed for grain size (using the Unified Soil Classification System, USCS). A set of British standard (BS) Sieves of sizes: $4.75 \mathrm{~mm}, 3.35 \mathrm{~mm}$, $2.36 \mathrm{~mm}, 1.18 \mathrm{~mm}, 600 \mu \mathrm{m}, 425 \mu \mathrm{m}, 300 \mu \mathrm{m}, 212 \mu \mathrm{m}$, $150 \mu \mathrm{m}, 75 \mu \mathrm{m}$, and receiver (pan) was used for this analysis. Atterberg limits, coefficient of permeability, compaction, and triaxial tests were determined in accordance with BS 1377 (1990). Results from the triaxial tests were plotted on a Mohr stress diagram (MohrView) to obtain values for cohesion and angle of internal resistance.
Results from the laboratory analysis were used to perform two-dimensional slope stability analysis using the general limit equilibrium (GLE) method integrated in the software SLOPE/W of GeoStudio for stability analysis of slopes. To study the relationship between the slope angle and the sliding mass volume, we constructed a two-dimensional homogeneous slope model from Slope/W GeoStudio version (2016) software based on the analysis type of the Morgenstern-Price limit equilibrium method. Morgenstern and Price (1965) method was preferred, because they allowed for various user-specified interslice force functions. The half-sine user specified interslice force function available in SLOPE/W was implemented to compute for factor of safety. The entry and exit function was used to find the slip centre and the potential failure surface.

The slope material parameters needed for this simulation are angle of internal friction, cohesion and unit weight. Based on geological and geotechnical data, interpretations were made and best possible mitigation measures were suggested.

\section{Results and discussion}

\section{Geotechnical characteristics}

Results of geotechnical characteristics of the slope materials (Table 1) showed that samples 1, 2 and 3 are medium-fine clayey sand materials while sample 4 is greyish silty clay. The average range of coefficient of permeability of samples 1,2 and 3 is $1.11 \times 10^{-6}-1.47 \mathrm{X}$ $10^{-6}$, while sample 4 is $9.51 \times 10^{-8} \mathrm{~m} / \mathrm{sec}$. The very low permeability to impermeable silty clay units that separates the sand units in the area have been identified to be the gliding plane for several landslides in the area (Okagbue 1992). The average range of the angle of internal friction and cohesion of samples 1,2 and 3 are $\left(28^{\circ}-30^{\circ}\right)$ and $(5 \mathrm{kPa}-8 \mathrm{kPa})$ respectively (Figs. 6, 7, 8), while sample 4 is $8^{\circ}$ and $43 \mathrm{kPa}$ respectively (Fig. 9). Samples 1, 2 and 3 are non-plastic, but have average liquid limits (LL) range of 23-26. Also, the liquid limits (LL), plastic limits (PL) and plasticity index (PI) of sample 4 are 75,36 and 39 respectively. Sowers and Sowers (1970) reported that PI $>31$ should be considered high and indicates high content of expansive clay while Bell (2007) classified clays with Liquid Limit (LL) range of 7090 as very high plasticity. This could explain why the clays in this area serve as gliding plane to several landslides.

From our geotechnical results, we propose that shallow landslides in this area are triggered by water infiltration into high topographic gradient slopes where the poorly or unconsolidated sands overlies the less permeable clay/shale units. As the rainfall infiltrates the soil, the matric suction at shallow depths partially or completely disappears and therefore, the slope may fail. The reduction in soil matric suction decreases the soil shear 
Table 1 Selected geotechnical characteristics of the slope materials

\begin{tabular}{|c|c|c|c|c|c|c|c|}
\hline $\begin{array}{l}\text { Sample } \\
\text { number }\end{array}$ & $\begin{array}{l}\text { Cohesion } \\
(\mathrm{kPa})\end{array}$ & $\begin{array}{l}\text { Angle of internal friction } \\
\left({ }^{\circ}\right)\end{array}$ & $\begin{array}{l}\text { Coefficient of permeability } \\
(\mathrm{m} / \mathrm{sec})\end{array}$ & $\begin{array}{l}\text { Liquid } \\
\text { Limit }\end{array}$ & $\begin{array}{l}\text { Plastic } \\
\text { Limit }\end{array}$ & $\begin{array}{l}\text { Plasticity } \\
\text { Index }\end{array}$ & Grain size \\
\hline Nanka Sample 1 & 5 & 28 & $1.11 \times 10^{-6}$ & 24 & $\mathrm{~Np}$ & $\mathrm{~Np}$ & Clayey Sand \\
\hline Nanka Sample 2 & 6 & 29 & $1.47 \times 10^{-6}$ & 23 & $\mathrm{~Np}$ & $\mathrm{~Np}$ & Clayey Sano \\
\hline Nanka Sample 3 & 8 & 30 & $1.28 \times 10^{-6}$ & 26 & $\mathrm{~Np}$ & $\mathrm{~Np}$ & Clayey Sanc \\
\hline Nanka Sample 4 & 43 & 8 & $9.51 \times 10^{-8}$ & 75 & 36 & 39 & Silty Clay \\
\hline
\end{tabular}

Np Non-plastic

strength, and consequently causes the slope to become unstable and fail (Li et al. 2005). If the soil is completely saturated, soil matric suction will disappear completely and a perched water table with positive pore-water pressure will develop in the soil, this will lead to a reduction of the shear strength of the soil due to rise in pore-water pressure and loss of soil apparent cohesion, this will consequently trigger landslide (Fukuoka 1980; Wieczorek 1996; Li et al. 2005; Lee et al. 2012; Igwe et al. 2013).

\section{Impacts of landslides in Nanka}

Landslides have impacted Nanka area negatively in various forms and dimensions, but we will focus on the morphology of the land area, settlement region, agriculture and land cover. Generally, Nanka has an undulating topography/morphology ranging from gently sloping lowlands to slightly steep highlands. Morphologically, Nanka keeps evolving due to the effects of landslides and erosion. Gullies are widespread in Southeast Nigeria, but Nanka gully complex is the most outstanding in terms of extent and natural destruction (Okagbue 1992). The complex gullies have high slope angles ranging from $36^{\circ}-65^{\circ}$ based on field measurements, though in some inaccessible areas, the slope angles were estimated to be between $70^{\circ}$ and $80^{\circ}$. The depth of the gullies are over
$110 \mathrm{~m}$ in some places with a width of over $500 \mathrm{~m}$ based on field estimations. Landslides occur along the gully slopes especially during the rainy season, regular slides along the slopes persistently increase the width of the gullies and modify the morphology of the area. Yalcin (2007) reported that earth's surface is continually being modified by gravitational mass movements, particularly landslides. The surface of the earth, both on the continents and beneath the oceans is incessantly modified by internal forces and the forces of gravity (landslides). The net morphologic effect of landslides is to reduce slopes to angles at which they possess long-term stability (Schuster and Highland 2003).

Impacts of landslides on settlement area in Nanka have been disturbing. Okagbue (1992) reported the 1988 landslide in this area that destroyed several homes and over 50 families were evacuated. Interaction with some villagers revealed that over the years, several homes have been destroyed by landslide and many more are also threatened by this menace. The continuous increase of gully erosions which gives rise to unstable slopes that fail during short intense or long-term rainfalls have been the major cause of landslides in Nanka. Field observation showed some destroyed and abandoned buildings due to this hazard (Fig. 10). Lives and properties worth several millions of dollars have been lost due to the impact of

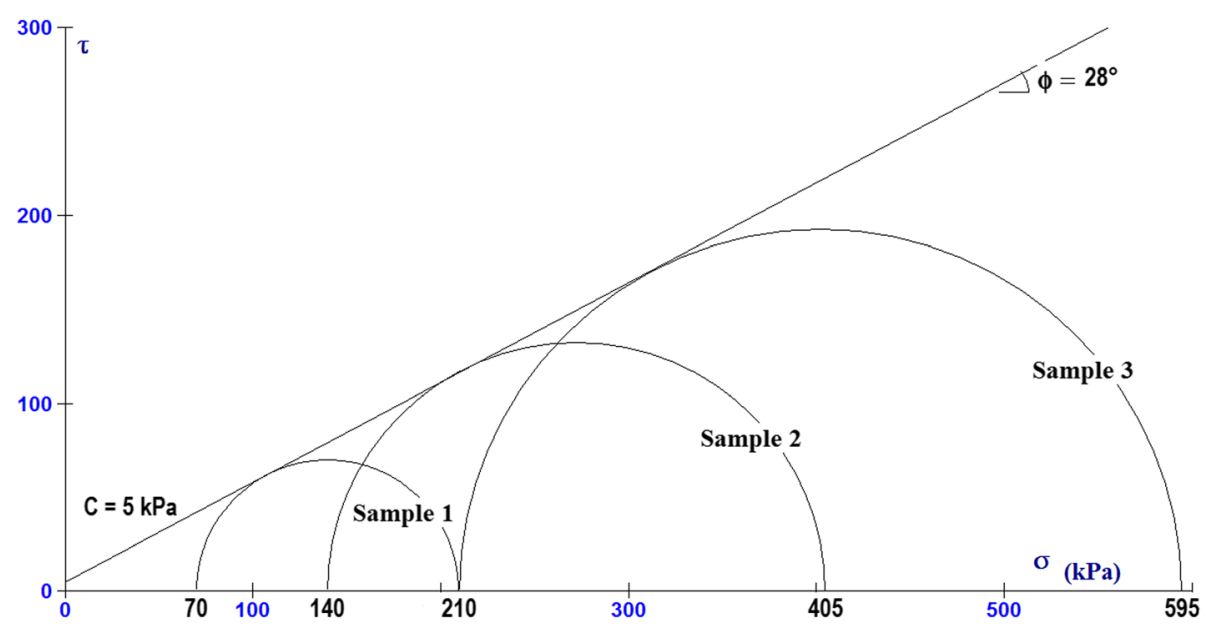

Fig. 6 Nanka sample 1 


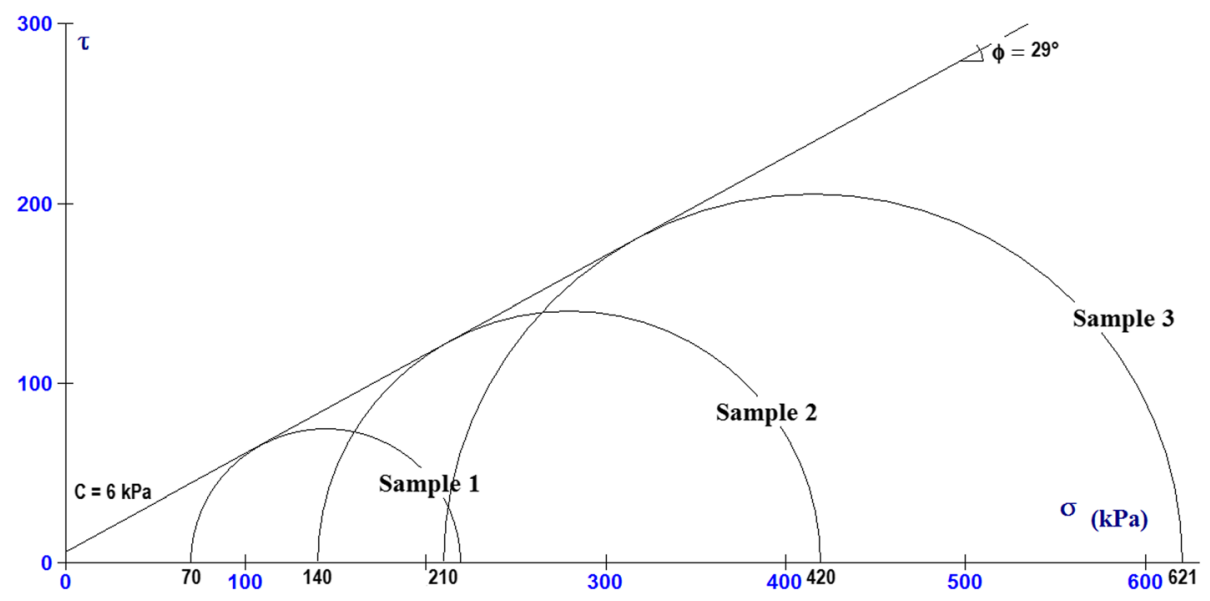

Fig. 7 Nanka sample 2

landslides on settlement areas in Nanka and its surrounding towns like Agulu, Oko and Ekwulobia.

Impacts of landslides on agriculture in the study area is overwhelming, many farmlands have been destroyed by landslides and some have been abandoned due to threats posed by this phenomenon. Loss of agricultural lands and livestock have been reported in this area by Okagbue (1992). Some of the residents who are mainly farmers have been affected tremendously because their main source of livelihood have been destroyed by landslides. Also, some have abandoned their farming business and engaged in petty trading due to this hazard. Agricultural lands keep reducing yearly and there is need for urgent intervention so that more lands will not be lost.

Landslides in Nanka have negative impact on the vegetation/land cover such that many areas have been left bare by continuous landslides. Widespread stripping of forest and vegetation cover by landslides has been noted in many parts of the world (Shaikh et al. 2005; Yalcin 2007). The nature of the slope materials and the long period of time that landslides occur in the area make it difficult for land cover recovery. Majorly, landslides occur in Nanka during the rainy season, which is from April to October, but interactions with local field guides and report from Okagbue (1992) revealed that landslides also occur during the dry season, which is between November and March. Bush burning for agricultural purpose also destroys the land cover and increase the potential of landslide occurrences. Generally, landslides have negatively affected the topography/morphology, settlement areas, agricultural lands and the land cover in Nanka area.

\section{Mitigation of landslides in Nanka}

Because of enormous damages caused by landslides globally, research and government institutions have for a long time attempted to decrease damages caused by it (Yalcin 2007). Landslides often are characterized as local problems, but their effects and costs frequently cross local jurisdictions and may become State or national problems (Highland and Bobrowsky 2008). This is the present state of Nanka; the cost of repairing damages

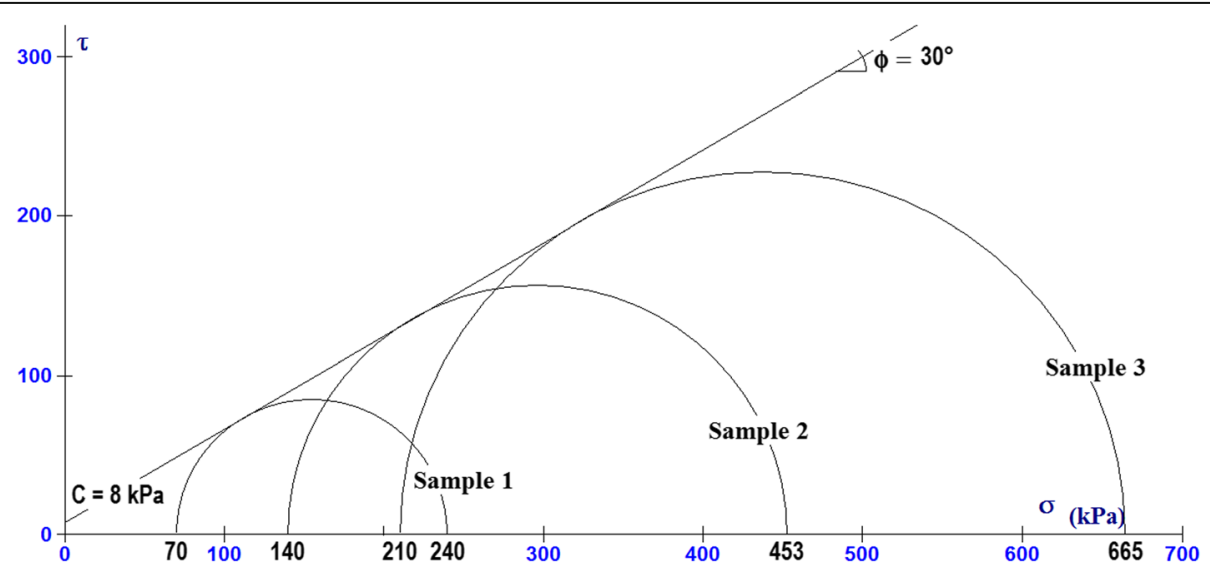

Fig. 8 Nanka sample 3 


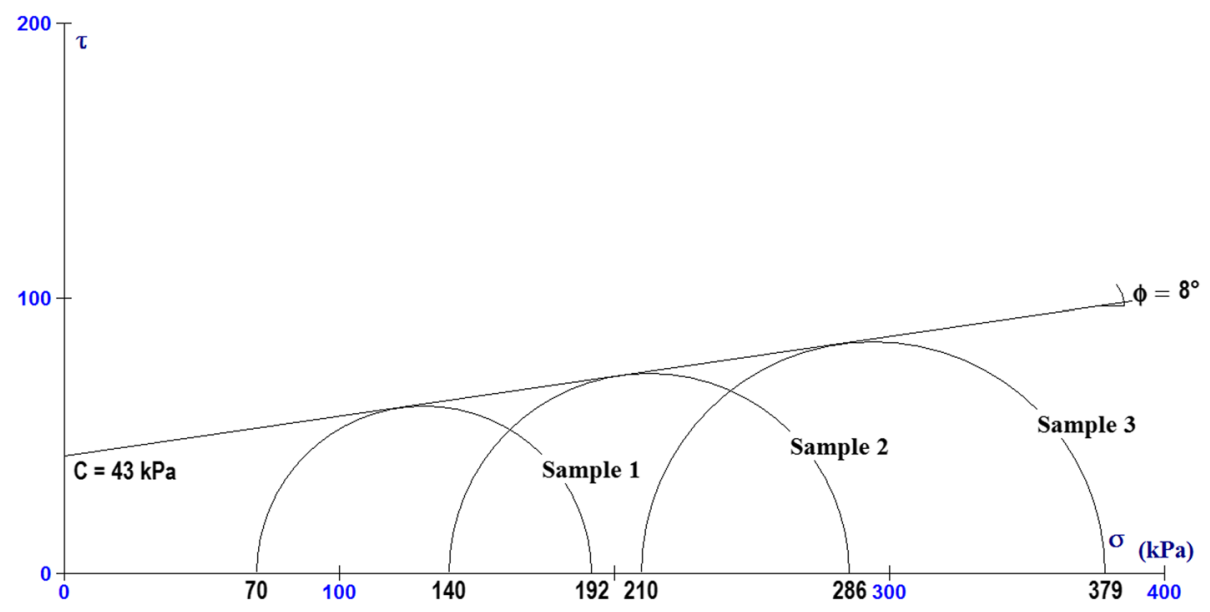

Fig. 9 Nanka sample 4

caused by landslides is beyond the local government and is now a national problem. Much of the problems caused by landslide in this area could have been curtailed long time ago, but due to lack of integrating landslide hazard information into local governments long-term plans. The Federal Government of Nigeria has spent huge amounts of naira in recent times to repair damages and mitigate future occurrences of landslides in this area. Field observations showed that the mitigation plans have failed and a better approach is needed urgently (Fig. 11). Our suggestions will be based on our understanding of the geology, geomorphology, hydrogeology and geotechnical characteristics of the area. Field observation revealed that most parts of Nanka do not have any drainage, while some places have poor drainage systems. We suggest a standard drainage system that is interconnected. A well-designed drainage system will decrease the amount of moisture entering the soils and thereby increasing the shear strength and slope stability. A

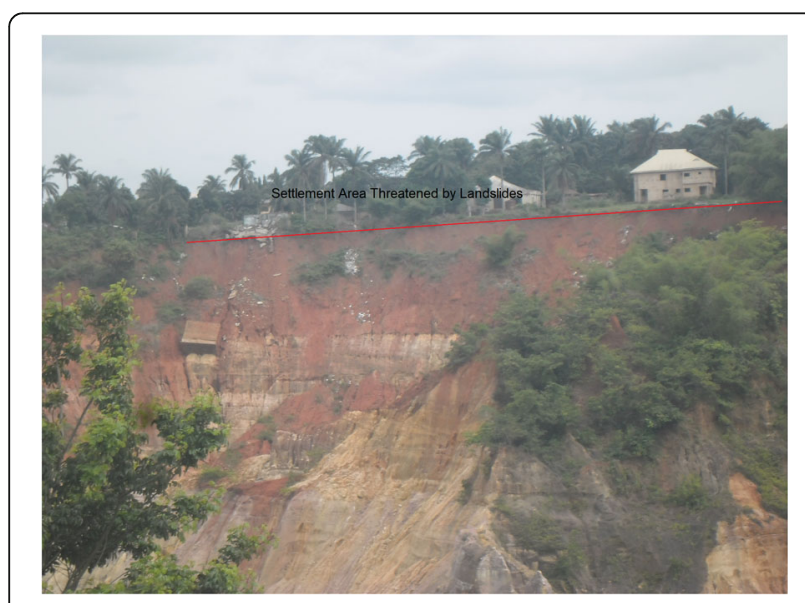

Fig. 10 Landslides and settlement area threatened by landsides similar method was proposed in East black sea region, Turkey by Yalcin (2007). The drainage is for the whole Nanka area, this will solve the problem of hill cuttings by erosion. Once the area is well drained, the effect of pore pressure in combination with gully erosions will be drastically reduced and consequently landslide occurrences will be reduced to the barest minimum. Highland and Bobrowsky (2008) reported that adequate drainage is necessary to prevent sliding or, in the case of an existing failure, to prevent a reactivation of the movement. Well-designed drainage system will not only prevent sliding, but will also prevent reactivation of movements on already failed areas in Nanka. After a good drainage system is constructed, the next step will be biotechnical slope protection. According to Gray and Sotir (1996),

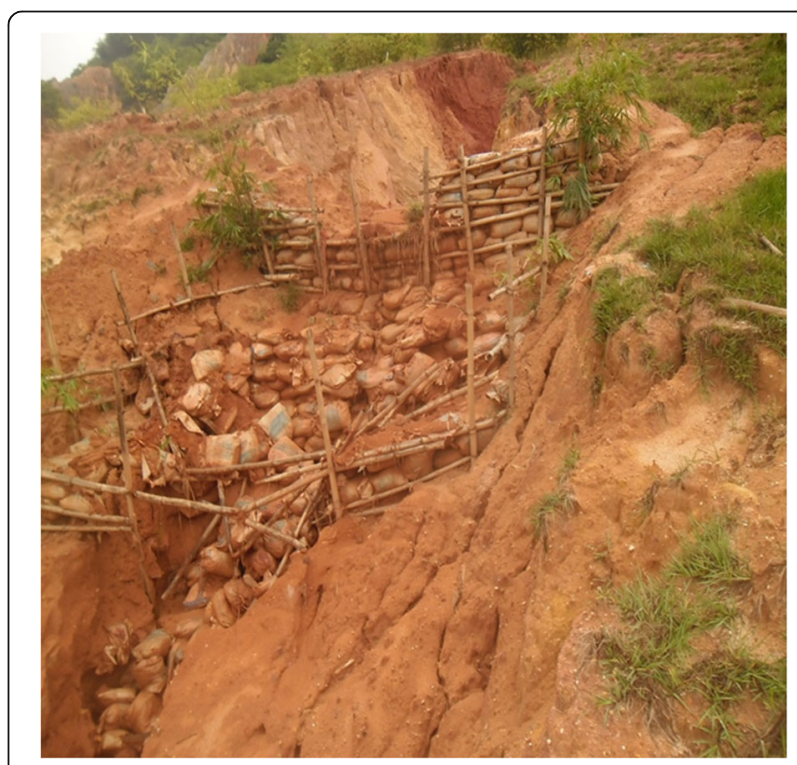

Fig. 11 Failed mitigation of gully erosion in Nanka 


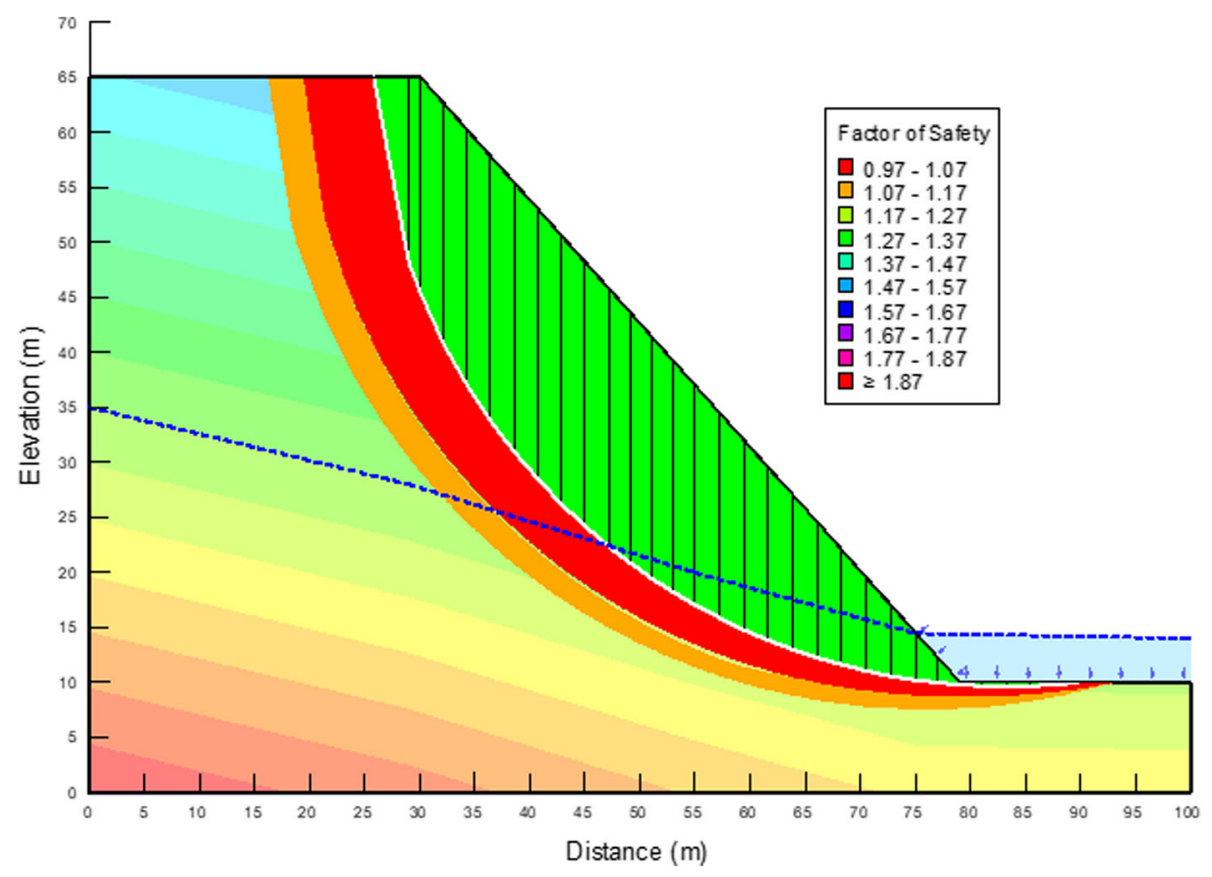

Fig. 12 Nanka simulation at slope angle of $40^{\circ}$

biotechnical slope protection consists of biotechnical stabilization and soil bioengineering stabilization, both of which entail the use of vegetation. Gray and Leiser (1982) said that biotechnical stabilization employs mechanical elements in combination with biological elements to prevent and arrest slope failures and erosion. While
Gray and Sotir (1996) asserted that soil bioengineering stabilization is a specialized subset of biotechnical stabilization in which live plant parts serve as mechanical elements in the slope protection system. Different plants that can stabilize the slopes should be planted by individuals and the government. Vetiver works very well

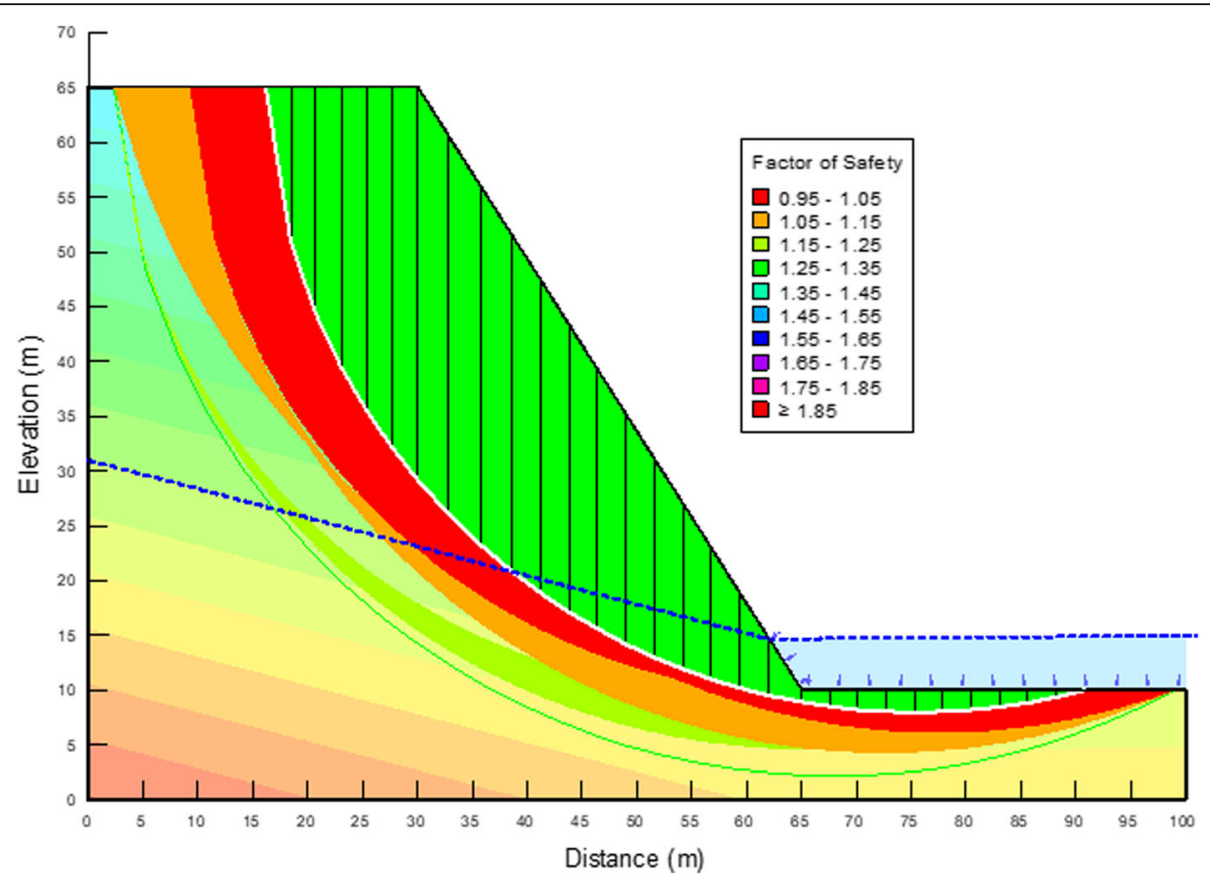

Fig. 13 Nanka simulation at slope angle of $50^{\circ}$ 


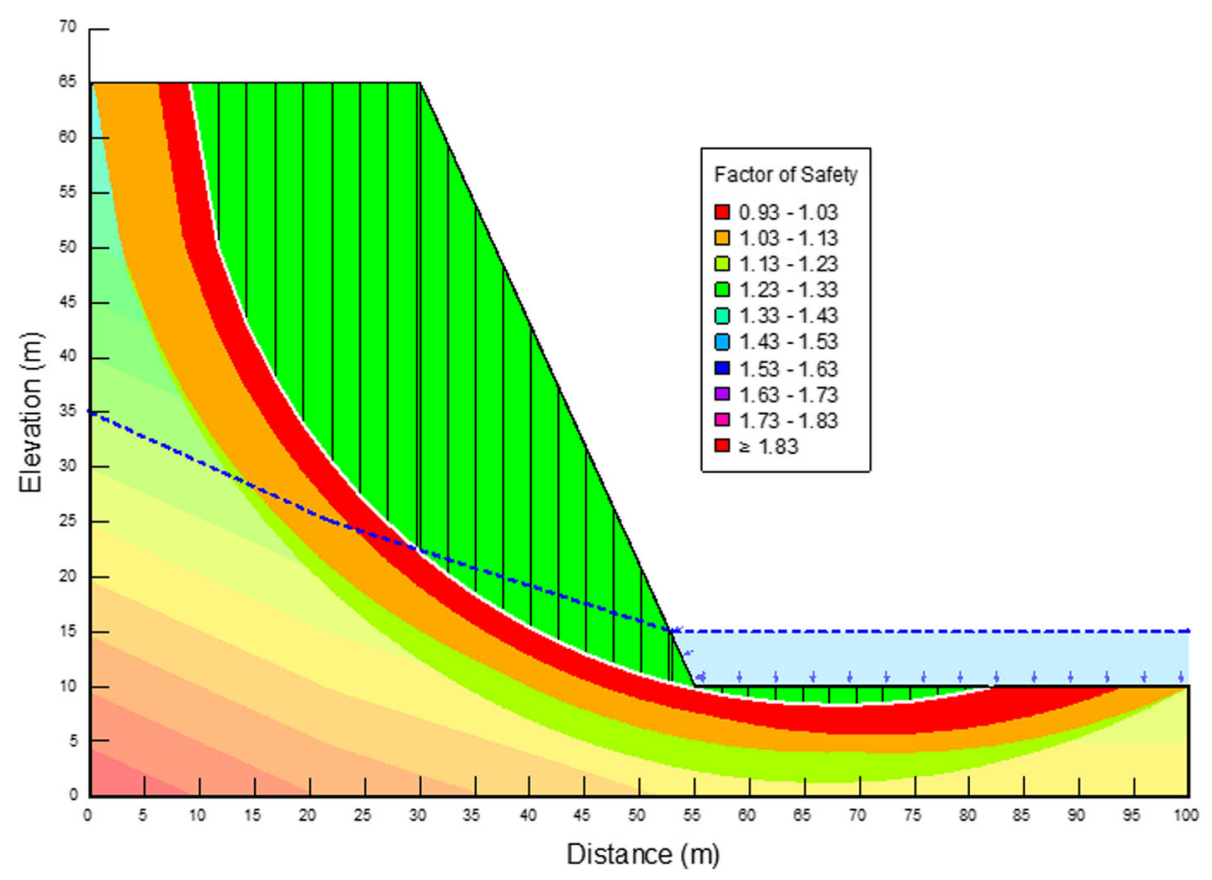

Fig. 14 Nanka simulation at slope angle of $60^{\circ}$

to stabilize slopes against erosion in many different environments (Highland and Bobrowsky 2008). Bamboo trees also works exceptionally well in the stabilization of slopes. Bamboo trees have been successfully used to stabilize slopes in some parts of Oko and Amucha in Southeast Nigeria. Farmers should be encouraged to plant trees and grasses that will help stabilize the slopes. Since Nanka area is dominated by shallow landslides, vegetation turfing is one of the most important mitigation measures for such areas (Singh 2010). Finally, we suggest that landslide hazard information should be incorporated into long-term plans for Nanka and other areas prone to landslides. The public should be aware of the hazards and preventive measures.

Table 2 Summary of Statistics of Nanka

\begin{tabular}{llll}
\hline \multicolumn{4}{l}{ Summary statistics of Nanka } \\
\hline & Length $(\mathrm{m})$ & Width $(\mathrm{m})$ & Slope Angle $\left(^{\circ}\right)$ \\
\hline Count & 120 & 120 & 120 \\
Average & 12.457 & 2.16042 & 47.9583 \\
Standard deviation & 10.233 & 1.33303 & 6.70431 \\
Coeff. of variation & $82.15 \%$ & $61.70 \%$ & $13.98 \%$ \\
Minimum & 1 & 0.4 & 36 \\
Maximum & 40 & 7 & 65 \\
Range & 39 & 6.6 & 29 \\
\hline
\end{tabular}

\section{Limit equilibrium simulations}

The limit equilibrium simulations have been widely used to analyze slope stability problems. A slope is stable if it meets a set need for a fixed period with an acceptable safety factor. A factor of safety is defined as that factor by which the shear strength of the soil must be reduced in order to bring the mass of soil into a state of limiting equilibrium along a selected slip surface (Slope/W 2016).

Most of the slope angles measured during the field studies ranged between $40^{\circ}$ and $60^{\circ}$, therefore, our limit equilibrium simulations to model the slopes will have three representative slope angles $\left(40^{\circ}, 50^{\circ}\right.$ and $\left.60^{\circ}\right)$. The

Table 3 Correlation of Landslide dimensions and slope angle

\begin{tabular}{llll}
\hline Nanka Correlations & & & \\
\hline & Length $(\mathrm{m})$ & Width $(\mathrm{m})$ & Slope angle $\left(^{\circ}\right)$ \\
\hline Length $(\mathrm{m})$ & & 0.444 & 0.4887 \\
& & $(120)$ & $(120)$ \\
& & 0 & 0 \\
Width $(\mathrm{m})$ & 0.444 & & 0.289 \\
& $(120)$ & & $(120)$ \\
& 0 & & 0.0014 \\
Slope angle $\left(^{\circ}\right)$ & 0.4887 & 0.289 & \\
& $(120)$ & $(120)$ & \\
& 0 & 0.0014 & \\
\hline
\end{tabular}

Pearson correlation

(Sample Size)

$P$-Value 
Table 4 Principal components analysis of Nanka

\begin{tabular}{llll}
\hline Component Number & Eigenvalue & Percent of Variance & Cumulative Percentage \\
\hline 1 & 1.82005 & 60.668 & 60.668 \\
2 & 0.713122 & 23.771 & 84.439 \\
3 & 0.466831 & 15.561 & 100
\end{tabular}

slope material parameters needed for this simulation are cohesion, angle of internal friction, and unit weight based on the analysis type of the Morgenstern and Price (1965) limit equilibrium method. Morgenstern-Price is a general method of slices developed on the basis of limit equilibrium. It requires satisfying equilibrium of forces and moments acting on individual blocks.

We decided to make the slope material parameters constant for the three simulations and vary the slope angles, this is to help us understand the relationship between slope angle and landslide dimensions, and to reveal the safety map of the slope with colour map and factor of safety range. The simulations revealed that as the slope angle increases, the potential slip mass volume increases (Figs. 12, 13, 14). This could be because of slope height and slope base length obtainable in this area. This means that areas with higher slope angles will possibly have more potential mass volume. Our simulations agree with our observations in the field and with two dimensional discrete element numerical simulations by Katz et al. (2014). The factor of safety ranges at different slope angles revealed slight differences. The factor of safety ranges at slope angles of $60^{\circ}, 50^{\circ}$ and $40^{\circ}$ are $0.93-1.83,0.95-1.85$ and $0.97-1.87$ respectively. This implies that areas with higher slope angles will fail before areas with smaller slope angles under similar conditions. This is in agreement that lowering of slope angles in a given area will make the slope more stable.

\section{Statistical analysis of landslide dimensions and slope angle in Nanka}

Table 2 shows the summary statistics for the study area, the table revealed that the coefficient of variation is high in both landslide length and width, but minimal in the slope angle. The high coefficient of variation is due to the large differences in landslide dimensions observed in the field. The results of the Pearson correlations (Table 3) revealed that there is a moderate relationship between length and width of landslides in Nanka (0.444). The Pearson correlations showed that there is minimal relationship between length or width of landslides with the slope angle. This suggests that the slope angle does not really determine the length or width of landslides in the areas studied. The results of the principal component analysis (PCA) shows the loading of variables on each component and percentage of data variance in the data set (Table 4). The three components shown in the table accounted for $100 \%$ of the total variance in the data set with each component 1,2 and 3 having percentage variance of $60.668,23.771$ and 15.561. Using their high eigenvalues, only two components were extracted as principal components because they accounted for $84.439 \%$ of the total data variance. The results of PCA and Pearson correlation revealed that landslide dimensions are not categorically related to the slope angle, it implies that other factors such as nature of the slope material, geologic structures and hydrogeology could be more influential in determining the dimensions of the landslides in Nanka area.

\section{Conclusions}

The impacts and mitigations of landslides in Nanka, Anambra State, Southeast Nigeria were studied. A procedure that involved field, laboratory and limit equilibrium simulations were employed in the study. A total of 120 landslides in this area were documented during the field study, they were mainly shallow landslides with depth range of $0.2 \mathrm{~m}-1.8 \mathrm{~m}$ and slope angle range of $36^{\circ}-65^{\circ}$. Laboratory data revealed that the silty clay sample is highly plastic with low coefficient of permeability. This could explain why the clays in this area serve as gliding plane for several landslides. The limit equilibrium simulations revealed that as the slope angle increases, the potential slip mass volume increases, which implies that areas with higher slope angles will possibly have more potential mass volume. Our study of landslides in Nanka revealed that the topography/ morphology of the area have been negatively affected by landslides. Settlement areas and agricultural lands have been terribly devastated by this phenomenon. Houses, farm lands and livestock have been destroyed by landslides and many areas are also threatened by landslides. Continuous landslides have left many areas bare thereby having negative impact on the vegetation/land cover. Standard mechanical drainage system have been suggested as a mitigation measure to drastically reduce the impacts of landslides in this area. Biotechnical slope protection was also suggested as a mitigation measure to help stabilize unstable slopes and curb sliding. It will also restore the vegetation/land cover in the area. Finally, we suggested that landslide hazard information should be incorporated into long-term plans for Nanka and other areas prone to landslides, the public should be aware of the hazards and preventive measures. 


\section{Abbreviations}

KPa: Kilopascal; LL: Liquid Limits; M: Metres; NP: Non-plastic; PI: Plasticity index; PL: Plastic limits

\section{Acknowledgements}

Not applicable.

\section{Funding}

Not applicable.

\section{Availability of data and materials}

The dataset supporting the conclusions of this article is included within the article and its additional files.

\section{Authors' contributions}

IO conceived the study, participated in its design and coordination. UCO carried out the field/laboratory work and drafted the manuscript. All authors read and approved the final manuscript.

\section{Competing interests}

The authors declare that they have no competing interests.

\section{Publisher's Note}

Springer Nature remains neutral with regard to jurisdictional claims in published maps and institutional affiliations.

\section{Author details}

${ }^{1}$ Department of Geology, University of Nigeria, Nsukka, Nigeria. ${ }^{2}$ Department of Applied Geology, Wesley University, Ondo, Nigeria.

Received: 16 January 2019 Accepted: 9 May 2019

Published online: 16 May 2019

\section{References}

Ancuța, R., O. Daniel, and R. Paulică. 2007. Analysis of the landslide movements. International Journal of Geology 1 (3): 70-79.

Bell, F.G. 2007. Engineering geology. 2nd ed, 207-248. London: Elsevier.

Benkhelil, J. 1989. The origin and evolution of the cretaceous Benue trough (Nigeria). Journal of African Earth Sciences 8: 251-282.

Brand, E.W., J. Premchitt, and H.B. Phillipson. 1984. Relationship between rainfall and landslides. In Proceedings of the 4th inter-national symposium on landslides, vol. 1, 377-384. Toronto: BiTech publishers, Vancouver, B.C.

British Standards 1377. 1990. Methods of testing soil for civil engineering purposes, 1990. London: British Standards Institute.

Chen, C.Y. 2008. Sedimentary impacts from landslides in the Tachia River basin. Taiwan. Geomorphology. https://doi.org/10.1016/j.geomorph.2008.10.009.

Chowdhury, R.N., and P.N. Flentje. 2014. Mitigation of landslide impacts, strategies and challenges for the 21st century. International Journal of Landslide and Environment 2 (1): 1-13.

Cruden, D.M., and D.J. Varnes. 1996. Landslide types and processes. In Special report 247: Landslides investigation, mitigation, ed. A.K. Turner and R.L. Schuster, 36-75. Washington, DC: National Research Council, Transportation Research Board.

Dai, F.C., F.C. Lee, and Y.Y. Ngai. 2002. Landslide risk assessment and management: an overview. Engineering Geology 64: 65-87.

Egboka, B.C.E., and E.I. Okpoko. 1984. Gully erosion in the Agulu-Nanka region of Anambra State, Nigera. Challenges in African hydrology and water resources (proceedings of the Harare symposium, July 1984). IAHS Publication Oxfordshire UK no. 144.

Ezechi, J.I. 1987. An engineering geology study of some selected gully sites in Eastern Nigeria. Nsukka: M.Sc. Thesis, University of Nigeria.

Ezemonye, M.N., and C.N. Emeribe. 2012. Rainfall erosivity in southeastern Nigeria. Ethiopian Journal of Environmental Studies and Management 5 (2): 112-122.

Fukuoka, M. 1980. Landslides associated with rainfall. Geotechnical Engineering 11: $1-29$.

GEO-SLOPE International Ltd. 2015. Stability modeling with SLOPEM 2016 version. Printed in Canada, 244.

Gray, D.H., and A.T. Leiser. 1982. Biotechnical slope protection and Erosion control, 271. New York: Van Nostrand Reinhold Company.

Gray, D.H., and R.B. Sotir. 1996. Biotechnical and soil bioengineering slope stabilization - A practical guide for Erosion control, 378. New York: Wiley.
Highland, L.M., and P. Bobrowsky. 2008. The landslide handbook-A guide to understanding landslides: Reston, Virginia, U.S. Geological Survey circular 1325, 129.

Hungr, O., S.G. Evans, M.J. Bovis, and J.N. Hutchinson. 2001. Review of the classification of landslides of the flow type. Environmental and Engineering Geoscience 7: 221-238.

Ibeanu, A.M., and O.P. Umeji. 2003. Aspects of the Palaeocology of Okigwe cuesta, eastern Nigeria. West African journal of Archaeology 31 (1): 17-30.

Igwe, O. 2015. The geotechnical characteristics of landslides on the sedimentary and metamorphic terrains of Southeast Nigeria, West Africa. Geoenvironmental Disasters 2 (1): 1-14.

Igwe, O., W. Mode, O. Nnebedum, I. Okonkwo, and I. Oha. 2013. The analysis of rainfall-induced slope failures at Iva Valley area of Enugu state, Nigeria. Environment and Earth Science. https://doi.org/10.1007/s12665-013-2647-x.

Katz, O., J.K. Morgan, E. Aharonov, and B. Dugan. 2014. Controls on the size and geometry of landslides: Insights from discrete element numerical simulations. Geomorphology 24: 104-113.

Kazmi, D., S. Qasim, I.S.H. Harahap, S. Baharom, M. Mehmood, F.I. Siddiqui, and M. Imran. 2017. Slope remediation techniques and overview of landslide risk management. Civil Engineering Journal 3 (3): 180-189.

Kogbe, C.A. 1989. Palaeogeographic history of Nigeria from Albian times. In Geology of Nigeria, ed. C.A. Kogbe, 257-275. Lagos: Elizabethan Publ. Co.

Lateltin, O., C. Haemmig, H. Raetzo, and C. Bonnard. 2005. Landslide risk management in Switzerland. Landslides 2: 313-320.

Lee, C.C., L.S. Zeng, C.H. Hsieh, and C.Y. Yu. 2012. Determination of mechanisms and hydrogeological environments of Gangxianlane landslides using geoelectrical and geological data in Central Taiwan. Environment and Earth Science 66 (6): 1641-1651

Li, A.G., Z.Q. Yue, L.G. Tham, C.F. Lee, and K.T. Law. 2005. Field-monitored variations of soil moisture and matric suction in a saprolite slope. Canadian Geotechnical Journal 42: 13-26.

Monanu, S., and F. Inyang. 1975. Climatic regimes. In Nigeria in Maps (ed. by, ed. G.E.K. Ofomata, 27-29. Benin: Ethiope Publ. House.

Morgenstern, N.R., and V.E. Price. 1965. The analysis of the stability of general slip surfaces. Geotechnique 15: 79-93.

Murat, R.C. 1972. Stratigraphy and paleogeography of the Cretaceous and Lower Tertiary in Southern Nigeria. In African Geology, ed. T.F.J. Dessauvagie and A.J. Whiteman, 251-266. Nigeria: University of Ibadan Press.

Nwachukwu, U.E.D., O.A. Anyiam, O.C. Egbu, and I.S. Obi. 2011. Sedimentary controls on the reservoir properties of the paleogenefluvio-tidal sands of the Anambra Basin, southeastern Nigeria-implication for Deepwater reservoir studios. American Journal of Scientific and Industrial Research 2 (1): 37-48.

Nwajide, C.S. 1980. Eocene tidal sedimentation in the Anambra Basin, southern Nigeria. Sedimentary Geology 25: 189-207.

Nwajide, S.C. 1977. Sedimentology and stratigraphy of the Nank sand. M.Phil. Thesis, Dept. of Geology. Nsukka: University of Nigeria.

Oboh-Ikuenobe, F.E., G.C. Obi, and C.A. Jamarillo. 2005. Lithofacies, palynofacies and sequence stratigraphy of paleogene strata in southeastern Nigeria. Journal of African Earth Sciences 41: 79-101.

Ogbukagu, I.M. 1976. Soil erosion in the northern parts of Awka-Orlu uplands, Nigeria. Nigerian Journal Mining \& Geology 13: 6-19.

Okagbue, C.O. 1986. Gully development and advance in a rain forest of Nigeria. In Proc. 5th congr. Int. Assoc. Eng Geol. Buenos Aires, 1999-2010.

Okagbue, C.O. 1992. The 1988 Nanka landslide, Anambra state, Nigeria. Bulletin of the International Association of Engineering Geology 46 (1): 79-87.

Schuster, R.L., and L.M. Highland. 2003. Impact of landslides and innovative landslidemitigation measures on the natural environment. Proceedings of the international conference on slope engineering. Hong Kong: University of Hong Kong.

Shaikh, A.A., K. Gotoh, and K. Tachiiri. 2005. Multitemporal analysis of land cover changes in Nagasaki city associated with natural disasters using satellite remote sensing. Journal of Natural Disaster Science 27 (1): 9-15.

Singh, A.K. 2010. Bioengineering techniques of slope stabilization and landslide mitigation. Disaster Prevention and Management 19 (3): 384-397.

Sowers, G.B., and G.E. Sower. 1970. Introductory soil mechanics and foundations, 337. London: Macmillan Book Publishing Company.

Terlien, M. 1998. The determination of statistical and deterministic hydrological landslide- triggering thresholds. Environmental Geology 35 (2-3): 124-130.

Wieczorek, G.F. 1996. Landslides triggering mechanisms. In Landslides investigation and mitigation, ed. A.K. Turner, 76-90. Washington: National Research Council, Transportation Research Board.

Yalcin, A. 2007. Environmental impacts of landslides: A case study from East Black Sea region, Turkey. Environmental Engineering Science 24 (6): 821-833. 